\title{
Factors Affecting Yields and Essential Oil Quality of Ocimum sanctum L. and Ocimum basilicum L. Cultivars
}

\author{
Kelly M. Bowes and Valtcho D. Zheljazkov ${ }^{1}$ \\ Department of Plant and Animal Sciences, Nova Scotia Agricultural College, Truro, N.S., Canada \\ B2N $5 E 3$
}

\begin{abstract}
ADDITIONAL INDEX WORDS. freeze-dried, air-dried, transplant date, cultivar
AbSTRaCt. Field and laboratory experiments were conducted during the summers of 2001 and 2002 in two locations in Nova Scotia to identify the effect of cultivar, transplanting date, and drying (air-drying and freeze-drying) on basil (Ocimum basilicum 'Mesten' and 'Italian Broadleaf', and O. sanctum 'Local') productivity and oil quality in Nova Scotia and to identify the potential of growing basil as a cash crop in this region. Results suggested that all of the tested cultivars of basil grown in Nova Scotia had acceptable yields and composition for the international commercial market.

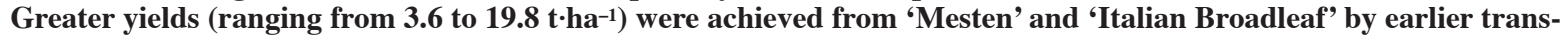
planting. 'Local' had a lower oil content compared to the other cultivars. Linalool was the main component of 'Mesten' oil, linalool and methyl chavicol were the main components of 'Italian Broadleaf' oil, while elemene and $\alpha$-humulene were the main components of 'Local' oil. Both air-drying and freeze-drying were found to alter the composition of the essential oil from $O$. sanctum and $O$. basilicum.
\end{abstract}

Basil belongs to the genus Ocimum L., which has an estimated 150 different species (Javanmardi et al., 2002). The essential oil of basil is widely utilized as an aromatic agent in the food, pharmaceutical, cosmetic, and aromatherapy industries. Research has found that basil essential oil possesses antimicrobial (Elgayyar et al., 2001) and insecticidal (Bowers and Nishida, 1980) properties, making it potentially suitable for use as a constituent in organic pesticides and natural preservatives. The essential oil is most commonly extracted by steam distillation of fresh stems, leaves, and flowers. However, if extraction is not immediately possible then drying before distillation may be necessary.

The main components of $O$. basilicum essential oil are linalool, methyl chavicol, camphor, and methyl eugenol (Gill and Randhawa, 1996; Marotti et al., 1996; Pino et al., 1994), which vary in relative amounts depending on the chemotype of the plant. Eugenol is the main component (30\% to $70 \%$ ) of O. sanctum (Kelm and Nair, 1998). In addition to drying conditions, location (Javanmardi et al., 2002) and cultivar (Lachowiez et al., 1997) can have a significant effect on both the content and composition of essential oil. Gill and Randhawa (1996) have reported an effect of transplanting date on basil essential oil composition with linalool increasing with each delay in transplanting while methyl chavicol and eugenol showed an associated decrease.

The method of drying basil herbage before oil extraction can significantly affect the essential oil content and quality (Grayer et al., 1996; Yousif et al., 1999). Yousif et al. (1999) reported

Received for publication 2 Feb. 2004. Accepted for publication 19 May 2004. We thank Minas Seed Inc. for providing a field site and logistics, James Pincock, Dalhousie University for providing access and to and assistance with the GC/MS system and the Cropping Systems Research Program at NSAC for technical support. We thank Drs. Jeff Hoyle and Nancy Crowe from Environmental Sciences Department of NSAC for critical review of the manuscript and suggested improvements. This study has been supported by a NSERC grant awarded to K. Bowes and by AAFC and NS Technology Development Program project \# DEV20-079 to V. Zheljazkov.

1To whom reprint requests should be addressed. E-mail: vjeliazkov@nsac.ns.ca that air-dried and fresh samples of basil had similar oil content and yields, but differed from those acquired from tissues that had previously been vacuum-microwave-dried. The same authors also showed that basil should be dried at temperatures below 40 ${ }^{\circ} \mathrm{C}$ to prevent essential oil losses and that freeze-drying did not show the reduction of oil quality that may be associated with heat damage. There was, however, a lower methyl chavicol to linalool ratio noted in the oil distilled from freeze-dried basil (Grayer et al., 1996).

Various chemotypes of $O$. basilicum are being traded on the international market. European basil, with linalool and methyl chavicol as the main components, is often considered to have the finest flavor. Reunion basil has high levels of methyl chavicol and the main component of tropical chemotype is methyl cinnamate. Another type that is high in eugenol is grown in northern Africa, Russia, eastern Europe, and parts of Asia (Marotti et al., 1996).

There is a significant interest in basil as a prospective new cash crop in Nova Scotia, but the infrastructure (commercial steam distillation units) for essential oil extraction has not been developed in the region yet. Therefore, growers need to consider drying the basil, or other alternative conservation methods prior to distillation at a central location. It is necessary to determine if these treatments will affect the quality and yields of the essential oil. In addition, there is no information on how transplanting date, and cultivar affect basil productivity and oil quality in this region.

This study evaluated species and cultivars of basil as potential new cash crops for essential oil production in Nova Scotia. The predominate agricultural land in Nova Scotia is located in plant hardiness zones 5 and 6 . Furthermore, most horticultural crops in Atlantic Canada are grown in Nova Scotia, in the area around Canning and some in the area around Truro. Also, growers in the region are looking for new cash crops. Hence, in order to make our study more representative, we have chosen to conduct the experiment at two sites representing plant hardiness zone 5 (Truro) and 6 (Canning). 
The objectives of this study were to determine the effect of transplanting dates and drying method on productivity, essential oil content and composition of two cultivars of $O$. basilicum and one cultivar of $O$. sanctum. To meet these objectives, two year field and in-lab experiments were conducted during 2001 and 2002 in two locations in Nova Scotia (Truro and Canning). Three cultivars (O. basilicum 'Mesten' and 'Italian Broadleaf', and O. sanctum 'Local') and two transplanting dates (6 and 20 June) were tested in the field experiments. In addition, an in-lab experiment was conducted to determine the affect of air-drying and freeze-drying on basil essential oil composition and yields.

\section{Materials and Methods}

EXPERIMENTAL DESIGN. The field experiments were conducted using a two by three factorial design with one blocking factor (location within the field). The factors investigated were: planting date (6 and 20 June) and cultivar (O. basilicum 'Mesten' and 'Italian Broadleaf', and O. sanctum 'Local'). The experiments were conducted in Truro and Canning, Nova Scotia, in 2001 and repeated in 2002. In addition, to determine the effect of freezedrying and air-drying of basil herbage on essential oil composition and yield, an in-lab experiment was conducted, using a two by three factorial design [cultivar (Local and Mesten) and preparation (fresh, air-dried, and freeze-dried)].

Plant and growth Conditions. Ocimum basilicum 'Mesten' and 'Italian Broadleaf' were chosen based on previous research indicating high productivity and quality of essential oil and the typical essential oil quality that is currently being marketed on the international market (Zheljazkov, 1998; Zheljazkov and Warman, 2003). Ocimum sanctum 'Local' is a new cultivar. Seeds of $O$. sanctum 'Local' and $O$. basilicum 'Mesten' were acquired from the Research Institute for Roses, Aromatic and Medicinal Plants, in Kazanlak, Bulgaria. Seeds of O. basilicum 'Italian Broadleaf' were purchased from Jonny's Selected Seeds (Winslow, Maine). These seeds were sown on 26 Apr. (for the first planting date) and on 12 May (for the second planting date) in transplant trays filled with Pro-Mix BX (Premier Horticulture Ltd., Dorval, Que.), a potting mix made of Canadian sphagnum peat moss, horticultural grade perlite, vermiculite, dolomitic limestone, calcitic limestone, macronutrients, micronutrients, and a wetting agent. The trays were fertilized weekly with $20 \mathrm{~N}-8.8 \mathrm{P}-16.6 \mathrm{~K}$ (5 $\left.\mathrm{g} \cdot \mathrm{L}^{-1}\right)$ and watered daily. The seedlings were grown for $50 \mathrm{~d}$ in the greenhouse facilities at the Nova Scotia Agricultural College, in Truro, Nova Scotia, prior to transplanting. Mean daytime and nighttime temperatures and durations were $25^{\circ} \mathrm{C} / 14 \mathrm{~h}$ and 18 ${ }^{\circ} \mathrm{C} / 10 \mathrm{~h}$, respectively.

The plants were hardened off prior to planting in the field. In both years, the two transplanting dates were 6 and 20 June. Basil was transplanted with $18-\mathrm{cm}$ spacing in three rows per plot, $70 \mathrm{~cm}$ apart in trenches (30 cm deep), to assist in the furrow irrigation. Plants were irrigated immediately after transplanting and three times during the growing season.

Soil testing was conducted prior to transplanting to estimate the available nutrients in the two locations. Based on soil testing and basil nutrient requirements, nitrogen $\left(51 \mathrm{~kg} \cdot \mathrm{ha}^{-1} \mathrm{~N}\right)$, in Truro and Canning, and potassium $\left(171 \mathrm{~kg} \cdot \mathrm{ha}^{-1} \mathrm{~K}\right)$ in Truro, were applied before final land preparation and mixed uniformly with the soil. Additional nitrogen $\left(34 \mathrm{~kg} \cdot \mathrm{ha}^{-1} \mathrm{~N}\right)$ was applied as a side dressing once during the growing season.
Plumdale soil had a pH of 6.8 and contained $67 \%$ sand, $7.8 \%$ silt, $25 \%$ clay, $2.8 \%$ organic matter $(\mathrm{OM}), 1160 \mathrm{~kg} \cdot \mathrm{ha}^{-1} \mathrm{P}, 332$ $\mathrm{kg} \cdot \mathrm{ha}^{-1} \mathrm{~K}, 4044 \mathrm{~kg} \cdot \mathrm{ha}^{-1} \mathrm{Ca}, 247 \mathrm{~kg} \cdot \mathrm{ha}^{-1} \mathrm{Mg}, 43 \mathrm{~kg} \cdot \mathrm{ha}^{-1} \mathrm{Na}, 46$ $\mathrm{kg} \cdot \mathrm{ha}^{-1} \mathrm{~S}, 229 \mathrm{mg} \cdot \mathrm{kg}^{-1} \mathrm{Fe}, 39 \mathrm{mg} \cdot \mathrm{kg}^{-1} \mathrm{Mn}, 21.5 \mathrm{mg} \cdot \mathrm{kg}^{-1} \mathrm{Cu}, 5.9$ $\mathrm{mg} \cdot \mathrm{kg}^{-1} \mathrm{Zn}, 0.69 \mathrm{mg} \cdot \mathrm{kg}^{-1} \mathrm{~B}, 15.3 \mathrm{meq} / 100 \mathrm{~g}$ cation exchange capacity (CEC). Canning soil had a pH of 6.5 and contained $47 \%$ sand, $48 \%$ silt, $4.6 \%$ clay, $2.9 \%$ OM, $366 \mathrm{~kg} \cdot \mathrm{ha}^{-1} \mathrm{P}, 193 \mathrm{~kg} \cdot \mathrm{ha}^{-1}$ $\mathrm{K}, 2313 \mathrm{~kg} \cdot \mathrm{ha}^{-1} \mathrm{Ca}, 546 \mathrm{~kg} \cdot \mathrm{ha}^{-1} \mathrm{Mg}, 58 \mathrm{~kg} \cdot \mathrm{ha}^{-1} \mathrm{Na}, 41 \mathrm{~kg} \cdot \mathrm{ha}^{-1} \mathrm{~S}$, $165 \mathrm{mg} \cdot \mathrm{kg}^{-1} \mathrm{Fe}, 73 \mathrm{mg} \cdot \mathrm{kg}^{-1} \mathrm{Mn}, 2.5 \mathrm{mg} \cdot \mathrm{kg}^{-1} \mathrm{Cu}, 1.3 \mathrm{mg} \cdot \mathrm{kg}^{-1} \mathrm{Zn}$, $0.39 \mathrm{mg} \cdot \mathrm{kg}^{-1} \mathrm{~B}$, and $12.2 \mathrm{meq} / 100 \mathrm{~g} \mathrm{CEC}$. The content of above soil nutrients was established by Mehlich 3 extraction procedure (Mehlich, 1984) and subsequent measurements on an inductively coupled argon plasma spectrometer (ICAP).

Basil plants were harvested when the plants were at the flowering stage, when the content and quality of essential oil is the highest (Gill and Randhawa, 1996; Topalov, 1962). Plants were cut $5-10 \mathrm{~cm}$ above the ground and fresh yields were recorded. In 2002, subsamples (300 g) were taken for immediate extraction and another sub sample from each plot was immediately freezedried. The remaining basil was air-dried.

SAMPLE PREPARATION, ESSENTIALOILEXTRACTION,AND GAS CHROMATOGRAPHY ANALYSES. Plants for the air-dried treatments in the in-lab experiment were placed in a forced-air drier at $27^{\circ} \mathrm{C}$ for $5 \mathrm{~d}$. Freeze-dried samples were placed on aluminum plates and dried at $-50{ }^{\circ} \mathrm{C}$ for $24 \mathrm{~h}$ under vacuum conditions (Association of Official Analytical Chemists, 1980). Oil extraction was performed within $12 \mathrm{~h}$ of harvest for all fresh tissue samples.

Steam distillation was used to extract the essential oil using a modified Clevenger collector apparatus (Guenther, 1942) from Bibby Sterilin Ltd. (Staffordshire, England). The distillations were carried out on sample size of $300 \mathrm{~g}$ of fresh material $(\approx 100$ $\mathrm{g}$ dried) with a distillation time of $120 \mathrm{~min}$ (30 min after the last additional oil volume change). Oil volume was recorded and oil yield was calculated as the volume (milliliters) of oil per weight (gram) of fresh basil tissue.

Oil samples were analyzed by gas chromatography (GC) with both mass spectrum (MS) and flame ionization detection (FID). Analysis was performed by adding $0.5 \mathrm{~mL}$ of glass-distilled hexane to $50 \mathrm{~mL}$ of oil. The GC column was a Supelco MDN-55 fused silica capillary column, $30 \mathrm{~m} \times 0.25 \mathrm{~mm}$ i.d., with a film thickness of $0.5 \mathrm{~mm}$. The temperature program had an initial temperature of $75^{\circ} \mathrm{C}$, which was held for $4 \mathrm{~min}$, followed by 4 ${ }^{\circ} \mathrm{C}$ per min increase with a total run time of $35 \mathrm{~min}$. The injection volume was $1.0 \mathrm{~mL}$ and the injector temperature was $240^{\circ} \mathrm{C}$. The helium carrier gas flow rate was $1.0 \mathrm{~mL} \cdot \mathrm{min}^{-1}$ for GC-MS and 2.0 $\mathrm{mL} \cdot \mathrm{min}^{-1}$ for FID analysis. Multiple standards were purchased from Aldrich Canada (Ontario) for comparison of retention times and MS spectrum. Both FID and MS analyses were performed and component identification was made based on matching retention times and MS of unknown components with the identified standards. For comparative quality analysis with commercial basil oils were purchased from ATL Canada (Ontario).

Statisticalanalysis. All data sets were analyzed using a two way analysis of variance (SAS Institute, 2000). In responses where the interactions or main effects were found significant at $P<0.05$, a Tukey's test was performed for means separation. Constant variance and normality of residuals were tested. To achieve a normal distribution of residuals, results from the two locations were analyzed separately and some transformations were performed as necessary. 


\section{Results and Discussion}

Field EXPERIMENT. The delayed planting resulted in lower fresh yields from basil grown in Truro (2001 and 2002) and Canning (2002) (Table 1). Furthermore, fresh yields from the two cultivars of $O$. basilicum ('Italian Broadleaf' and 'Mesten') outperformed $O$. sanctum 'Local.' Fresh yields from 2001 ranged from 5.5 to $19.8 \mathrm{t}^{\cdot} \cdot \mathrm{ha}^{-1}$. The fresh yields of $O$. basilicum cultivars grown in Australia (4.48 to $16.24 \mathrm{t}^{\cdot \mathrm{ha}^{-1}}$ with a mean of 11.23 tha ${ }^{-1}$ ) (Lachowiez et al., 1997) were similar to the fresh yields of the $O$. basilicum cultivars grown in Nova Scotia. Summer 2002 had less precipitation than the previous summer and the unusual drought for the region reduced basil yields. It is important to note that for successful production of basil, supplemental irrigation may be necessary in Nova Scotia during some summers. Even in 2002 with the lower yields, basil grown in Nova Scotia had acceptable fresh yields.

The results indicate that the essential oil accumulation in Nova Scotia grown basil is high with contents reaching $0.91 \%$ of fresh basil tissue. The essential oil yields (dependent on both essential oil content and plant yield) ranged from 0.6 to $13.8 \mathrm{~L} \cdot \mathrm{ha}^{-1}$ with a mean of $4.06 \mathrm{~L}^{\cdot h a^{-1}}$ (Table 1). Essential oil contents ranging from $0.07 \%$ to $1.37 \%$ (Pino et al., 1994; Wetzeil et al., 2002) have been reported elsewhere. Essential oil content and yield of the two cultivars of $O$. basilicum were greater than $O$. sanctum 'Local.' Similar to results reported here, Lachowiez et al. (1997) reported that cultivar affected the essential oil yield. Planting date did not affect oil content or oil yields except for Truro in 2002 where 'Italian Broadleaf' from 6 June had the greatest oil yield.

Basil essential oil distilled from the air-dried stems, leaves and flowers contained: 1,8-cineole, carene, linalool, methyl chavicol, eugenol, elemene, $\alpha$-humulene, and cadine (Tables 1-4). There were two unknown components referred to as "w" and "x," which were not identified. Eugenol, elemene, and " $x$ " were increased by the delayed planting date and 1,8-cineole was lower in the oil from the plants planted on 20 June. In Canning in 2002, the $\alpha$-humulene was reduced in plants from the second planting date. Between the three cultivars there was great variation in the composition of the essential oil. Marotti et al. (1996) grouped cultivars according to the main component in basil essential oil. If this classification is followed, the oil of 'Mesten' oil could be classified as type one chemotype with linalool as the main component. Further, $O$. basilicum 'Italian Broadleaf' oil could be classified as type two chemotype or in the international market as European basil oil with linalool and methyl chavicol as the two main components. The 'Local' basil oil contained mainly elemene, carene and $\alpha$ humulene, a chemotype not previously reported.

The oil composition of the two $O$. basilicum cultivars in our study was similar to those reported for the 10 cultivars examined by Marotti et al. (1996) with linalool as the main component (41\% to 76\%). Marotti et al. (1996) also reported relatively high levels of 1,8 -cineole ( $1 \%$ to $12 \%$ ), similar to the levels in the cultivars from our study ( $1.3 \%$ to $24.1 \%)$. The effect of transplanting date reported here differs from those reported by Gill and Randhawa (1996) who found that delayed transplanting date increased the linalool content in the oil. 1,8-cineole content from Gill and Randhawa (1996) was in agreement with results from 2002 in Nova Scotia, decreasing with the later transplanting date. Furthermore, eugenol content in basil from Canning in 2001, similar to the previously mentioned study, was lower in the latter planting date. Gill and Randhawa (1996) also found that with delay of planting, methyl chavicol decreased. Our results suggest that planting date did not affect methyl chavicol content. These differences possibly indicate that the effect of transplanting date may be counteracted by other more influential factors such as genotype, climate, and other growing conditions (Javanmardi et al., 2002). Our results indicate that the composition of the essential oil was not significantly altered by the difference in a transplanting date.

Overall the composition of the oil from the three cultivars tested in Nova Scotia would be suitable for commercial sales. The content was found to be similar to the composition of commercially available basil oils from India, France, Australia, and Seychellea that were analyzed by Lachowiez et al. (1996). In addition, commercial basil essential oils were purchased and

Table 1. The growth response of basil grown in Nova Scotia as effected by cultivar, location and transplanting date.

\begin{tabular}{|c|c|c|c|c|c|c|}
\hline \multirow[b]{4}{*}{ Growth response } & \multicolumn{6}{|c|}{ Cultivar } \\
\hline & \multicolumn{2}{|c|}{ Mesten } & \multicolumn{2}{|c|}{ Italian Broadleaf } & \multicolumn{2}{|c|}{ Local } \\
\hline & \multicolumn{6}{|c|}{ Planting date } \\
\hline & 6 June & 20 June & 6 June & 20 June & 6 June & 20 June \\
\hline & \multicolumn{6}{|c|}{ Basil grown in Canning in 2001} \\
\hline Fresh yields $\left(t \cdot h^{-1}\right)$ & $9.8 \mathrm{bc}^{\mathrm{z}}$ & $15.5 \mathrm{ab}$ & $19.8 \mathrm{a}$ & $13.7 \mathrm{abc}$ & $9.5 \mathrm{bc}$ & $8.2 \mathrm{c}$ \\
\hline Oil content ( $\mathrm{mL} / 100 \mathrm{~g}$ dried basil) & $0.91 \mathrm{a}$ & $0.74 \mathrm{a}$ & $0.72 \mathrm{a}$ & $0.79 \mathrm{a}$ & $0.14 \mathrm{~b}$ & $0.14 \mathrm{~b}$ \\
\hline \multirow[t]{2}{*}{ Oil yield $\left(\mathrm{L} \cdot \mathrm{ha}^{-1}\right)$} & $9.4 \mathrm{a}$ & $11.6 \mathrm{a}$ & $13.8 \mathrm{a}$ & $11.6 \mathrm{a}$ & $1.3 \mathrm{~b}$ & $0.9 \mathrm{~b}$ \\
\hline & \multicolumn{6}{|c|}{ Basil grown in Truro in 2001} \\
\hline Fresh yields $\left(\mathrm{t} \cdot \mathrm{ha}^{-1}\right)$ & $11.4 \mathrm{ab}$ & $7.1 \mathrm{c}$ & $13.6 \mathrm{ab}$ & $10.5 \mathrm{c}$ & $12.06 \mathrm{a}$ & $5.5 \mathrm{~b}$ \\
\hline Oil content ( $\mathrm{mL} / 100 \mathrm{~g}$ dried basil) & $0.35 \mathrm{a}$ & $0.65 \mathrm{a}$ & $0.60 \mathrm{a}$ & $0.47 \mathrm{a}$ & $0.14 \mathrm{~b}$ & $0.18 \mathrm{~b}$ \\
\hline \multirow[t]{2}{*}{ Oil yield $\left(\mathrm{L} \cdot \mathrm{ha}^{-1}\right)$} & $3.9 \mathrm{a}$ & $4.7 \mathrm{a}$ & $8.0 \mathrm{a}$ & $4.8 \mathrm{a}$ & $1.7 \mathrm{~b}$ & $1.0 \mathrm{~b}$ \\
\hline & \multicolumn{6}{|c|}{ Basil grown in Canning in 2002} \\
\hline Fresh yields $\left(\mathrm{t} \cdot \mathrm{ha}^{-1}\right)$ & $3.6 \mathrm{aA}$ & $2.2 \mathrm{aB}$ & $3.6 \mathrm{aA}$ & $2.9 \mathrm{aB}$ & $2.1 \mathrm{bA}$ & $1.8 \mathrm{bB}$ \\
\hline Oil content ( $\mathrm{mL} / 100 \mathrm{~g}$ dried basil) & $0.63 \mathrm{a}$ & $0.55 \mathrm{a}$ & $0.37 \mathrm{ab}$ & $0.53 \mathrm{ab}$ & $0.32 \mathrm{~b}$ & $0.44 \mathrm{~b}$ \\
\hline \multirow[t]{2}{*}{ Oil yield $\left(\mathrm{L} \cdot \mathrm{ha}^{-1}\right)$} & $2.2 \mathrm{a}$ & $1.0 \mathrm{a}$ & $1.5 \mathrm{a}$ & $1.6 \mathrm{a}$ & $0.6 \mathrm{~b}$ & $0.8 \mathrm{~b}$ \\
\hline & \multicolumn{6}{|c|}{ Basil grown in Truro in 2002} \\
\hline Fresh yields $\left(\mathrm{t} \cdot \mathrm{ha}^{-1}\right)$ & $6.3 \mathrm{~b}$ & $4.2 \mathrm{~b}$ & $7.8 \mathrm{a}$ & $5.1 \mathrm{a}$ & $6.11 \mathrm{ab}$ & $4.9 \mathrm{ab}$ \\
\hline Oil content ( $\mathrm{mL} / 100 \mathrm{~g}$ dried basil) & $0.54 \mathrm{a}$ & $0.64 \mathrm{a}$ & $0.68 \mathrm{a}$ & $0.53 \mathrm{a}$ & $0.35 \mathrm{~b}$ & $0.35 \mathrm{~b}$ \\
\hline Oil yield $\left(\mathrm{L} \cdot \mathrm{ha}^{-1}\right)$ & $3.3 \mathrm{~b}$ & $2.6 \mathrm{~b}$ & $5.2 \mathrm{a}$ & $2.7 \mathrm{~b}$ & $2.2 \mathrm{~b}$ & $1.8 \mathrm{~b}$ \\
\hline
\end{tabular}

${ }^{\mathrm{z}}$ Means of cultivar and date by cultivar interactions followed by different lowercase letters are significantly different at $P<$ 0.05 . 
Table 2. The major components of essential oil of basil grown in Nova Scotia in 2001 as affected by cultivar, location, and transplanting date.

\begin{tabular}{|c|c|c|c|c|c|c|}
\hline \multirow{4}{*}{$\begin{array}{l}\text { Components of } \\
\text { essential oils }\end{array}$} & \multicolumn{6}{|c|}{ Cultivar } \\
\hline & \multicolumn{2}{|c|}{ Mesten } & \multicolumn{2}{|c|}{ Italian Broadleaf } & \multicolumn{2}{|c|}{ Local } \\
\hline & \multicolumn{6}{|c|}{ Planting date } \\
\hline & 6 June & 20 June & 6 June & 20 June & 6 June & 20 June \\
\hline & \multicolumn{6}{|c|}{ Basil grown in Canning } \\
\hline 1,8-cineole & 10.3 & 7.4 & 5.6 & 5.4 & 5.7 & 11.2 \\
\hline carene & $0.08 \mathrm{bz}^{\mathrm{z}}$ & n.d. ${ }^{y} b$ & n.d. b & $0.11 \mathrm{~b}$ & $14.32 \mathrm{a}$ & $23.44 \mathrm{a}$ \\
\hline linalool & $56.6 \mathrm{a}$ & $65.2 \mathrm{a}$ & $51.1 \mathrm{c}$ & $47.4 \mathrm{~b}$ & $1.5 \mathrm{c}$ & n.d. c \\
\hline methyl chavicol & $0.6 \mathrm{~b}$ & $1.1 \mathrm{~b}$ & $37.6 \mathrm{a}$ & $35.5 \mathrm{a}$ & $6.3 \mathrm{~b}$ & $8.5 \mathrm{~b}$ \\
\hline eugenol & $2.3 \mathrm{ab}$ & n.d.ab & n.d. b & $0.1 \mathrm{~b}$ & $3.8 \mathrm{a}$ & $1.5 \mathrm{a}$ \\
\hline unknown component "w" & $7.1 \mathrm{a}$ & $7.9 \mathrm{a}$ & $3.5 \mathrm{~b}$ & $3.4 \mathrm{~b}$ & $2.3 \mathrm{~b}$ & $1.6 \mathrm{~b}$ \\
\hline unknown component " $\mathrm{x}$ " & $2.3 \mathrm{~b}$ & $2.5 \mathrm{~b}$ & $1.5 \mathrm{~b}$ & $1.5 \mathrm{~b}$ & $4.4 \mathrm{a}$ & $5.1 \mathrm{a}$ \\
\hline elemene & $2.0 \mathrm{~b}$ & $1.9 \mathrm{~b}$ & $0.6 \mathrm{~b}$ & $0.5 \mathrm{~b}$ & $23.6 \mathrm{a}$ & $22.3 \mathrm{a}$ \\
\hline$\alpha$-humulene & $0.02 \mathrm{~b}$ & n.d. b & n.d. b & n.d. b & $19.15 \mathrm{a}$ & $20.61 \mathrm{a}$ \\
\hline \multirow[t]{2}{*}{ cadine } & $2.4 \mathrm{a}$ & $2.0 \mathrm{a}$ & n.d. b & $0.6 \mathrm{~b}$ & n.d. b & n.d. b \\
\hline & \multicolumn{6}{|c|}{ Basil grown in Truro } \\
\hline 1,8-cineole & 6.3 & 10.4 & 9.7 & 10.8 & 5.2 & 10.4 \\
\hline carene & n.d. b & n.d. b & n.d. b & n.d. $b$ & $8.85 \mathrm{a}$ & $17.77 \mathrm{a}$ \\
\hline linalool & $52.8 \mathrm{a}$ & $68.1 \mathrm{a}$ & $47.0 \mathrm{a}$ & $51.0 \mathrm{a}$ & $2.5 \mathrm{~b}$ & n.d. b \\
\hline methyl chavicol & n.d. c & n.d. c & $27.3 \mathrm{a}$ & $32.4 \mathrm{a}$ & $10.0 \mathrm{~b}$ & $6.8 \mathrm{~b}$ \\
\hline eugenol & n.d. b & n.d. b & n.d. b & n.d. b & $3.7 \mathrm{a}$ & $2.7 \mathrm{a}$ \\
\hline unknown component "w" & $6.8 \mathrm{a}$ & $7.3 \mathrm{a}$ & $2.7 \mathrm{~b}$ & $3.2 \mathrm{~b}$ & $2.3 \mathrm{~b}$ & $1.2 \mathrm{~b}$ \\
\hline unknown component " $\mathrm{x}$ " & $2.4 \mathrm{~b}$ & $3.7 \mathrm{~b}$ & $0.7 \mathrm{c}$ & $1.7 \mathrm{c}$ & $6.4 \mathrm{a}$ & $6.4 \mathrm{a}$ \\
\hline elemene & $2.0 \mathrm{~b}$ & $1.4 \mathrm{~b}$ & $0.8 \mathrm{~b}$ & $0.5 \mathrm{~b}$ & $32.9 \mathrm{a}$ & $26.0 \mathrm{a}$ \\
\hline$\alpha$-humulene & n.d. b & n.d. b & n.d. b & n.d. b & $24.31 \mathrm{a}$ & $22.56 \mathrm{a}$ \\
\hline cadine & $1.5 \mathrm{a}$ & $2.1 \mathrm{a}$ & $0.8 \mathrm{ab}$ & $0.4 \mathrm{ab}$ & n.d. b & $0.3 \mathrm{~b}$ \\
\hline
\end{tabular}

zMeans of cultivar and date by cultivar interactions followed by different lowercase letters are significantly different at $P<0.05$. yNot detected.

Table 3. The major components of essential oil of basil grown in Nova Scotia in 2002, as affected by cultivar, location, and transplanting date.

\begin{tabular}{|c|c|c|c|c|c|c|}
\hline \multirow{4}{*}{$\begin{array}{l}\text { Components of } \\
\text { essential oils }\end{array}$} & \multicolumn{6}{|c|}{ Cultivar } \\
\hline & \multicolumn{2}{|c|}{ Mesten } & \multicolumn{2}{|c|}{ Italian Broadleaf } & \multicolumn{2}{|c|}{ Local } \\
\hline & \multicolumn{6}{|c|}{ Planting date } \\
\hline & 6 June & 20 June & 6 June & 20 June & 6 June & 20 June \\
\hline & \multicolumn{6}{|c|}{ Basil grown in Canning } \\
\hline 1,8-cineole & $10.8 b^{z}$ & $1.3 \mathrm{~b}$ & $12.5 \mathrm{~b}$ & $13.3 \mathrm{~b}$ & $2.40 \mathrm{a}$ & $24.1 \mathrm{a}$ \\
\hline carene & n.dy $b$ & $0.24 b$ & n.d. b & n.d. b & $4.52 \mathrm{a}$ & $5.07 \mathrm{a}$ \\
\hline linalool & $53.76 \mathrm{a}$ & $48.6 \mathrm{a}$ & $41.8 \mathrm{~b}$ & $43.3 \mathrm{~b}$ & $1.1 \mathrm{c}$ & $2.3 \mathrm{c}$ \\
\hline methyl chavicol & $0.7 \mathrm{c}$ & $0.7 \mathrm{c}$ & $26.3 \mathrm{a}$ & $22.5 \mathrm{a}$ & $10.6 \mathrm{~b}$ & $13.9 \mathrm{~b}$ \\
\hline eugenol & $3.2 \mathrm{a}$ & $2.7 \mathrm{a}$ & $0.5 \mathrm{~b}$ & $1.1 \mathrm{~b}$ & $3.9 \mathrm{a}$ & $3.9 \mathrm{a}$ \\
\hline unknown component "w" & $5.9 \mathrm{a}$ & $5.8 \mathrm{a}$ & $3.1 \mathrm{~b}$ & $3.5 \mathrm{~b}$ & $3.3 \mathrm{~b}$ & $2.6 \mathrm{~b}$ \\
\hline unknown component " $\mathrm{x}$ " & $3.4 \mathrm{a}$ & $3.3 \mathrm{a}$ & $1.9 \mathrm{c}$ & $2.1 \mathrm{c}$ & $2.8 \mathrm{~b}$ & $2.4 \mathrm{~b}$ \\
\hline elemene & $2.1 \mathrm{~b}$ & $2.2 \mathrm{~b}$ & $1.8 \mathrm{~b}$ & $1.8 \mathrm{~b}$ & $29.7 \mathrm{a}$ & $21.5 \mathrm{a}$ \\
\hline$\alpha$-humulene & n.d. b & n.d. b & n.d. b & n.d. b & $15.29 \mathrm{a}$ & $10.96 \mathrm{a}$ \\
\hline \multirow[t]{2}{*}{ cadine } & $3.9 \mathrm{a}$ & $4.0 \mathrm{a}$ & $3.1 \mathrm{~b}$ & $3.0 \mathrm{~b}$ & n.d. c & n.d. c \\
\hline & \multicolumn{6}{|c|}{ Basil grown in Truro } \\
\hline 1,8-cineole & $3.7 \mathrm{~b}$ & $5.6 \mathrm{~b}$ & $6.8 \mathrm{a}$ & $7.1 \mathrm{a}$ & $9.6 \mathrm{a}$ & $4.3 \mathrm{a}$ \\
\hline carene & n.d. b & n.d. b & n.d. b & $0.24 \mathrm{~b}$ & $3.10 \mathrm{a}$ & $0.23 \mathrm{~b}$ \\
\hline linalool & $55.3 \mathrm{a}$ & $52.7 \mathrm{a}$ & $47.1 \mathrm{a}$ & $27.8 \mathrm{a}$ & $0.5 \mathrm{~b}$ & $12.6 \mathrm{~b}$ \\
\hline methyl chavicol & $0.6 \mathrm{c}$ & $0.3 \mathrm{c}$ & $21.2 \mathrm{a}$ & $21.3 \mathrm{a}$ & $8.8 \mathrm{~b}$ & $10.6 \mathrm{~b}$ \\
\hline eugenol & $1.8 \mathrm{a}$ & $3.3 \mathrm{a}$ & $1.5 \mathrm{ab}$ & $1.0 \mathrm{ab}$ & $1.21 \mathrm{~b}$ & $0.87 \mathrm{~b}$ \\
\hline unknown component "w" & $8.6 \mathrm{a}$ & $6.5 \mathrm{a}$ & $2.6 \mathrm{~b}$ & $2.9 \mathrm{~b}$ & $3.3 \mathrm{~b}$ & $4.0 \mathrm{~b}$ \\
\hline unknown component " $\mathrm{x}$ " & $4.6 \mathrm{a}$ & $3.6 \mathrm{a}$ & $2.4 \mathrm{~b}$ & $2.2 \mathrm{~b}$ & $2.8 \mathrm{~b}$ & $2.3 \mathrm{~b}$ \\
\hline elemene & $2.5 \mathrm{~b}$ & $2.4 \mathrm{~b}$ & $2.0 \mathrm{~b}$ & 8.2 & $36.3 \mathrm{a}$ & $31.6 \mathrm{a}$ \\
\hline$\alpha$-humulene & n.d. b & n.d. b & n.d. b & $3.68 \mathrm{~b}$ & $17.48 \mathrm{a}$ & $10.93 \mathrm{a}$ \\
\hline cadine & $5.0 \mathrm{a}$ & $4.2 \mathrm{a}$ & $3.6 \mathrm{~b}$ & $2.2 \mathrm{~b}$ & n.d. c & $1.0 \mathrm{c}$ \\
\hline
\end{tabular}

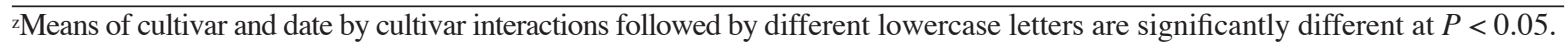
yNot detected. 
Table 4. The major components of essential oil of fresh, air-dried and freeze-dried basil herbage grown in Canning and Truro, N.S., as affected by cultivar and herbage drying method.

\begin{tabular}{|c|c|c|c|c|c|c|}
\hline \multirow{4}{*}{$\begin{array}{l}\text { Components of } \\
\text { essential oils }\end{array}$} & \multicolumn{6}{|c|}{ Cultivar } \\
\hline & \multicolumn{3}{|c|}{ Mesten } & \multicolumn{3}{|c|}{ Local } \\
\hline & \multicolumn{6}{|c|}{ Drying method } \\
\hline & Fresh & Freeze-dried & Air-dried & Fresh & Freeze-dried & Air-dried \\
\hline & \multicolumn{6}{|c|}{ Basil grown in Canning } \\
\hline 1,8-cineole & $8.4 \mathrm{~b}$ & $8.3 \mathrm{ab}^{\mathrm{z}}$ & $10.8 \mathrm{a}$ & $11.6 \mathrm{~b}$ & $14.1 \mathrm{ab}$ & $17.4 \mathrm{a}$ \\
\hline carene & $1.4 \mathrm{c}$ & $1.3 \mathrm{c}$ & n.d. d & $11.6 \mathrm{ba}$ & $11.1 \mathrm{a}$ & $4.5 \mathrm{~b}$ \\
\hline linalool & $50.8 \mathrm{a}$ & $35.7 \mathrm{~b}$ & $53.8 \mathrm{a}$ & $13.6 \mathrm{a}$ & n.d. c & $1.1 \mathrm{c}$ \\
\hline methyl chavicol & n.d. y $\mathrm{c}$ & n.d. c & $0.7 \mathrm{c}$ & $0.2 \mathrm{c}$ & $7.8 \mathrm{~b}$ & $10.6 \mathrm{a}$ \\
\hline eugenol & $5.4 \mathrm{~b}$ & $7.0 \mathrm{ab}$ & $3.8 \mathrm{~b}$ & $9.2 \mathrm{ab}$ & $5.3 \mathrm{ab}$ & $3.9 \mathrm{~b}$ \\
\hline unknown component "w" & n.d. c & $7.1 \mathrm{a}$ & $5.9 \mathrm{~b}$ & $13.5 \mathrm{a}$ & $2.4 \mathrm{c}$ & $3.3 \mathrm{bc}$ \\
\hline unknown component "x" & 3.7 & 4.3 & 3.4 & $2.0 \mathrm{c}$ & 4.4 & 2.7 \\
\hline elemene & n.d. b & n.d. b & $2.06 \mathrm{a}$ & $4.89 \mathrm{a}$ & 20.6 ba & $29.7 \mathrm{a}$ \\
\hline$\alpha$-humulene & n.d. & n.d. & n.d. & $19.7 \mathrm{~b}$ & 14.2 & 15.3 \\
\hline \multirow[t]{2}{*}{ cadine } & $3.4 \mathrm{a}$ & $4.9 \mathrm{a}$ & $3.9 \mathrm{a}$ & $14.4 \mathrm{a}$ & n.d. b & n.d. b \\
\hline & \multicolumn{6}{|c|}{ Basil grown in Truro } \\
\hline 1,8-cineole & 4.6 & 5.9 & 3.8 & 11.4 & 10.5 & 9.6 \\
\hline carene & $16.7 \mathrm{a}$ & $1.3 \mathrm{a}$ & n.d. b & $18.6 \mathrm{a}$ & $16.5 \mathrm{a}$ & $3.1 \mathrm{a}$ \\
\hline linalool & 48.4 & 28.3 & 55.3 & 0.3 & n.d. & 0.5 \\
\hline methyl chavicol & 0.2 & n.d. & 0.6 & 5.6 & 6.9 & 8.8 \\
\hline eugenol & $3.2 \mathrm{ab}$ & $9.1 \mathrm{a}$ & $1.8 \mathrm{~b}$ & $7.5 \mathrm{ab}$ & $8.6 \mathrm{a}$ & $1.2 \mathrm{~b}$ \\
\hline unknown component "w" & n.d. c & $7.1 \mathrm{~b}$ & $8.6 \mathrm{a}$ & $1.4 \mathrm{c}$ & $2.3 \mathrm{bc}$ & $3.3 \mathrm{bc}$ \\
\hline unknown component " $x$ " & 5.5 & 4.5 & 4.6 & 3.6 & 3.6 & 2.8 \\
\hline elemene & n.d. d & n.d. d & $2.4 \mathrm{c}$ & $20.1 \mathrm{~b}$ & $20.2 \mathrm{~b}$ & $36.3 \mathrm{a}$ \\
\hline$\alpha$-humulene & n.d. & n.d. & n.d. & 14.5 & 16.9 & 17.5 \\
\hline cadine & 4.3 & 4.1 & 5.0 & 0.3 & n.d. & n.d. \\
\hline
\end{tabular}

${ }^{\mathrm{z}}$ Means followed by the same letter are not significantly different at $P<0.05$.

yot detected.

the composition determined following the same method as the oils from our experiments. We found that there was a wide range of composition of the commercially available types of oil from Bulgaria, Italy, and India. However, the compositions of the essential oil from our experiments were similar in composition to the purchased essential oils, suggesting that the oil from basil grown in Nova Scotia could be easily marketed.

DRYING EXPERIMENT. Essential oil composition was altered by drying fresh basil plants. The linalool content in the freeze-dried plants from Canning was reduced from $50 \%$ to $35 \%$ (Table 4). Essential oil from 'Mesten' (Canning) and 'Local' had higher levels of 1,8-cineole in the air-dried basil oil. The unknown component "w" was lowest in air-dried plants from both cultivars. Air-drying of 'Mesten' eliminated the presence of carene in the oil. The content of eugenol was highest in the oil of freeze-dried plants of 'Mesten' and 'Local' grown in Canning. In Canning-grown basil, the methyl chavicol was lower in the oil from freeze-dried compared to the air-dried 'Local' basil. The carene in the oil from Canning was lowest in the air-dried basil. Elemene in 'Local' was highest in the air-dried basil from both locations (Canning and Truro).

Basil oil obtained from air-dried plants has previously been found to have the same levels of linalool and methyl chavicol as fresh basil oil (Yousif et al., 1999). Freeze-drying, however, has been reported to cause a lower methyl chavicol : linalool ratio (Grayer et al., 1996). Our study also demonstrated that freezedrying could lower both linalool and methyl chavicol. The levels of these two compounds in basil oil obtained from vacuum-microwave dried plants have been found to be greater (Yousif et al.,
1999). Furthermore, proportions of methyl chavicol and linalool have been altered by drying (Lachowicz et al., 1996).

It is not unexpected that the composition of basil essential oil can be affected by drying methods. Composition of essential oil is known to be greatly influenced by many factors. As there are changes in the composition of the oil, the aroma and flavor would also be altered and this should be considered for the final use of the oil. As freeze-drying is a more expensive procedure and also caused compositional changes, this may not be the best method for producers and industry to consider.

Our study suggests that the three cultivars of basil grown in Nova Scotia had acceptable yields and composition for the international commercial market. Earlier transplanted basil performed better and each of the three cultivars had a unique composition. Drying method was found to alter the concentration of linalool, 1,8-cineole, the unknown component " $w$," carene, eugenol, methyl chavicol, and elemene. Concluded from experiments conducted is the three tested basil cultivars could be grown as essential oil crops in the Maritime region of Canada.

\section{Literature Cited}

Association of Official Analytical Chemists. 1980. Official methods of analysis. 13th ed. Washington, D.C.

Bowers,W.S. and R. Nishida. 1980. Juvocimenes: Potent juvenile hormones mimics from sweet basil. Science 209:1030-1332.

Elgayyar, M., F.A. Draughon, D.A. Golden, and J.R. Mount. 2001. Antimicrobial activity of essential oils from plants against selected pathogenic and saprophytic microorganisms. J. Food Protection 64:1019-1024.

Gill, B.S. and G.S. Randhawa. 1996. Effect of different transplanting 
dates and harvesting stages on the quality of French basil oil. J. Herb Spice Medicinal Plants 4:35-42.

Grayer, R.J., G.C. Kite, F.J. Goldstone, S.E. Bryan, P. Allan, and E. Putievsky. 1996. Infraspecific taxonomy and essential oil chemotypes in sweet basil, Ocimum basilicum. Phytochemistry 43:1033-1039.

Guenther, E. 1942. The essential oils. vol. 1. Van Nostrond Co., New York.

Javanmardi, J., A. Khalighi, A. Kashi, H.P. Bais, and J.M. Vivanco. 2002. Chemical characterization of basil (Ocimum basilicum L.) found in 'local' accessions and used in traditional medicines in Iran. J. Agr. Food Chem. 50:5878-5883.

Kelm, M.A. and M.G. Nair. 1998. Mosquitocidal compounds and a triglyceride, 1,3-dilinoleneoyl-2-palmitin, from Ocimum basilicum, J. Agr. Food Chem. 46:3092-3094.

Lachowicz, K.J., G.P. Jones, D.R. Briggs, F.E. Bienvenu, M.V. Palmer, S.S.T. Ting, and M. Hunter. 1996. Characteristics of essential oil from basil (Ocimum basilicum L.) grown in Australia. J. Agr. Food Chem. 44:877-881.

Lachowiez, K.J., G.P. Jones, D.R. Briggs, F.E. Bienvenu, M.V. Palmer, V. Mishra, and M.M. Hunter. 1997. Characteristics of plants and plant extracts from five cultivars of basil (Ocimum basilicum L.) grown in Australia, J. Agr. Food Chem. 45:2660-2665.

Marotti, M., R. Piccaglia, and E. Giovanelli. 1996. Differences in essential oil composition of basil (Ocimum basilicum L.) Italian cultivars related to morphological characteristics. J. Agr. Food Chem. 44:3926-3929.

Mehlich, A. 1984. Mehlich 3 soil extractant and modification of Mehlich 2 extractant. Commun. Soil Sci. Plant Anal. 15:1409-1416.

Pino, J.A., E. Roncal, A. Rosado, and I. Goire. 1994. The essential oil of Ocimum basilicum L. from Cuba. J. Essential Oil Res. 6:89-90.

SAS Institute. 2000. The SAS system for Windows version 8. SAS Inst., Cary, N.C.

Topalov, V.D. 1962. Essential oil and medicinal plants. Hr. G. Danov Press, Plovdiv, Bulgaria.

Wetzeil, S.B., H. Kruger, K. Hammer, and K. Bachmann. 2002. Investigations on morphological and molecular variability of Ocimum L. species. J. Herbs Spices Medicinal Plants 9:8183-187.

Yousif, A.N., C.H. Scaman, T.D. Durance, and B. Girard. 1999. Flavor volatiles and physical properties of vacuum-microwaves-and air-dried sweet basil (Ocimum basilicum L.). J. Agr. Food Chem. 47:4777-4781.

Zheljazkov, V.D. 1998. Basil.p.317-320. In: M. Phehlivanor, G. Moskov, B. Jankov, J. Terziev, V. Zheljazkov, and H. Yantcheva (eds.). Plant production edition 1. Academic edition of Higher Inst. Agr., Plovdiv, Bulgaria.

Zheljazkov, V.D. and P.R. Warman. 2003. Application of high Cu compost to Swiss chard and basil. Sci. Total Environ. 302:13-26. 